\title{
Legal Reform, Women's Empowerment and Social Change: The Case of Egypt
}

\author{
Mulki Al-Sharmani
}

Abstract In the last decade, new family laws have been passed in Egypt, with important ramifications for women. In this article, I argue that two issues diminish the transformative role that these reforms could play in strengthening Egyptian women's rights and achieving gender justice. First, despite the recently passed laws, the model of marriage that the state continues to uphold through its codes and courts is premised on gendered roles and rights for husbands and wives. This model, however, contradicts the realities of Egyptian marriages. Second, the incongruence between the agendas of different reform actors, their piecemeal approach, and their top-down and non-participatory strategies have impacted the reform outcomes in mixed ways. This has meant that the multidimensionality and the social-embeddedness of the process of lawmaking have not been adequately taken into account in the efforts undertaken by reform actors, thereby undermining the effectiveness and significance of these endeavours.

\begin{abstract}
1 Introduction
Within the last decade, a number of new family laws were passed in Egypt, with important ramifications for women. In 2000, a comprehensive procedural law (Personal Status Law, PSL No. 1) was passed, granting women the right to obtain no-fault divorce $(k h u l)$ in exchange for giving up their rights to dower and alimony. In 2004, new family courts were established introducing a mediation-based and family-sensitive legal process. Furthermore, in that same year, PSL No. 11 was passed, which set up a government fund through which female disputants are paid court-ordered alimony. Finally, in 2005, PSL No. 4 was passed, which extended divorced mothers' rights to child custody until their children (boy or girl) reach the age of 15. The outcomes of these reforms, however, have been mixed and for the most part still fall short of addressing the inequalities and vulnerabilities from which women suffer.
\end{abstract}

The aim of this article is to shed light on two issues, which complicate and perhaps diminish the transformative role that the new legal reforms could play in strengthening Egyptian women's rights and achieving gender justice. First, I argue that despite the recently passed laws, the institutional model of marriage that the state continues to uphold through its codes and court system is premised on gendered roles and rights for husbands and wives. This legal model of marriage; however, contradicts the realities of Egyptian marriages. Second, the incongruence between the agendas of different reform actors, their piecemeal approach, and their top-down and non-participatory strategies have impacted the reform outcomes in mixed ways. This has meant that the multidimensionality and the social-embeddedness of the process of lawmaking have not been adequately taken into account in the reform efforts undertaken by both state and non-state actors, thereby undermining the effectiveness and significance of these endeavours.

This article draws on an ongoing three-year ethnographic study of recent reforms in Egyptian personal status laws. The study started in January 2007. Field data was collected through interviews with female and male plaintiffs, judges, mediation specialists, lawyers, legislators, 
women's rights activists, public thinkers, religious scholars, and members of the religious establishment. ${ }^{1}$ In addition, court proceedings in family law cases were observed, and a content analysis of court records was conducted.

\section{Constructing marriage in modern Egyptian Family Laws}

Egypt, like all other Middle Eastern countries with the exception of Turkey, adopts family laws that are drawn from the doctrines of classical schools of Islamic law. Reform efforts thus have to engage with the model of marriage and marital relations that is sanctioned by Islamic legal schools. But is the Islamic model of marriage inherently discriminatory against women? Abu Odeh (2004) and Mir-Hosseini (2003) argue that the main schools of Islamic Jurisprudence share a gendered model of marriage in which the relations between husbands and wives tend to be hierarchical. In this model, Islamic marriage is based on a contractual agreement between a man and a woman in which the husband has the duty to provide for his wife and their offspring and in return, the wife avails of herself to him and puts herself under his authority and protection. The husband's exclusive right to his wife's sexual and reproductive labour is earned through and conditioned upon his economic role. This model of marriage does not recognise shared matrimonial resources. Whatever possessions and assets the wife brings to the marriage remain hers. Likewise, apart from maintenance for herself and her children, the wife cannot make claims to resources acquired by the husband during marriage. In addition, the husband has unilateral right to repudiation and polygamy.

Nonetheless, the schools of Islamic Jurisprudence show considerable difference in the specificity of spousal rights and duties; a plurality that often worked for women, as historical studies of pre-codification eras in the Muslim world show (Tucker 2008; Hallaq 2009). In fact, historians who studied the trajectories of modern Muslim family laws argue that the gender inequality and biases against women found in present day family codes cannot be simply explained away by their religious sources. For example, Abdel Rahim (1996) and Sonbol (2005) traced the discrimination against women that is embedded in modern laws to modernist notions of building cohesive nuclear families that could be disciplined and controlled by modern nation-states. Sonbol (2005) argues that the process of codification of Muslim family laws was not only based on the doctrines of one or several Islamic legal schools but also on borrowings from colonial European laws. She shows that the project of subject-making and nation-building that was undertaken by modern Muslim nationstates in the twentieth century incorporated modernist European notions that perceived nuclear families as the essential blocks for progressive and well-governed societies. This discourse shifted the purpose of marriage from regulating a contractual relationship between a man and woman to creating nuclear families and maintaining their cohesiveness. Modern nationstates saw the nuclear patriarchal family as the institution in which individuals were reproduced as citizens and dutiful members of the nation. To enable families to fulfil their roles in the process of subject-making, these states devised family laws that regulated the rights and duties of family members. Husbands were bestowed with the responsibility of heading the family and providing for its family members. In return for the protection and financial support that women and children received from the husband/father, they owed him obedience and submission.

Article 1 in Egypt's first codified family code, PSL No. 25 of 1920, defines a husband's main role as the provider for his wife, while the role of the latter is to be sexually available to the husband. The law, furthermore, makes a wife's right to her husband's financial support conditional on her fulfilment of her sexual role. To fulfil her sexual role, the wife is expected to be physically available in the conjugal home. Article 11 in PSL No. 25 stipulates that a wife who is found by the court to be disobedient (nashiz) loses her right to her husband's financial support. Disobedience is defined as a wife's refusal to reside in the conjugal home with her husband. The law stipulates that this home has to be adequate and safe and the court needs to ascertain that the wife's desertion was not due to a reason sanctioned by the social norms (urf). The law does not spell out what these reasons are, but it is commonly understood that these would include leaving the conjugal home to visit extended family or to seek education or healthcare. Whether a wife's leaving the conjugal home for work is considered a socially acceptable reason has been contested by litigants 
and judges. According to law PSL No. 100 of 1985 , if a wife has written in her marriage contract that she holds a job, a husband cannot bring an obedience ordinance case against her on the basis of her going out to work. A wife who receives a disobedience judgement from the court loses her right to financial support from her husband. ${ }^{2}$

The subsequent family code (PSL No. 25 of 1929) also granted both spouses unequal rights and was discriminatory against women in many aspects. Men had an unfettered right to unilateral repudiation and polygamy; they enjoyed full guardianship over their children, whereas women had highly restricted access to divorce and could not be the legal guardians of their children even when they were the custodial parents. The new Egyptian Child Law, which was passed in June 2008, grants custodial female parents guardianship over their children. However, existing personal status laws still deny this.

In 1979, the late President Sadat decreed PSL No. 44 of 1979, which included revolutionary reforms. PSL No. 44 protected working women from obedience ordinance suits from their husbands on the grounds of their leaving the conjugal home to work and affirmed their right to spousal financial support. Other reforms included a wife's automatic right to judicial divorce if her husband enters into a new marriage without her having to prove injury; and her right to the conjugal home in the case of divorce if she has the custody of the children. The new law also legislated mut'a (indemnity) for women who are divorced by their husbands without their desire or fault (Fawzy 2004). To avoid opposition from religious establishment, Islamist groups, and other conservative factions in the society, President Sadat decreed the law at a time when the Parliament was not in session. PSL No. 44 of 1979, however, was later annulled by the High Supreme Court in 1985 because the process through which it was passed was ruled to be unconstitutional. That same year, its replacement PSL No. 100 was passed. The new law lacked many of the revolutionary articles of its predecessor.

Thus, marriage as constructed by the Egyptian modern laws is one in which a husband supports his wife and children, provides for them an adequate and safe conjugal home, and is considered by the legal institution as the guardian and the leader of this family unit. In exchange, a wife is expected to fulfil the sexual needs of her husband, to be physically available in the conjugal home, and to care for the children, although she cannot claim guardianship over them. Her role is sexualised and her rights are unequal to her husband's. But does this institutional model of marriage fit with the lived experiences of Egyptian women and men?

\section{Lived experiences of marriage}

Marriage continues to be an important social institution in which Egyptians invest to seek stability, security and social acceptability as well as to forge social and economic alliances between families. For the women interviewed for this study, the process of getting married involved finding a partner, negotiating each partner's share of the costs of marriage, and entering into marriage with adequate protection against divorce and abandonment. However, these different aspects of the process were not necessarily congruent with one another. Negotiations and compromises had to be made. Some women strategised better than others, but still many entered into marriages which were inherently based on precarious foundations such as reliance on meagre resources that were shared with in-laws; husband's irregular employment status; discrepancy between husband's and wife's perceptions about their financial roles in the marriage and the realities of their economic needs; pursuit of partners with economic assets at the expense of emotional and educational compatibility; as well as the unequal and hierarchical legal rights and obligations of husbands and wives. Many of the interviewed women worked before marriage. Some continued to work after marriage either regularly or intermittently, while others discontinued. But the majority of the women were sceptical that their work strengthened their marital rights and relations.

The legal gendering of marriage takes place through the interplay between different state codes (i.e. labour, social security and family), which is often disempowering to women. It is not only the case that gendered notions of men and women's roles in family laws contribute to labour or social security laws that discriminate against women and their spouses. It is also the case that labour or social security laws that discriminate 
against women destabilise their marriages. For example, widowed women are sometimes forced to enter into unregistered marriages (urfi), in which they can make no legal claims to financial support or inheritance from their second husbands, so that they can keep the pensions of their deceased partners. Also, in the course of this research, I have come across married women in their sixties whose husbands did not support their families because either they earned very little and intermittently from informal labour, or because they were absent partners who repeatedly abandoned and then returned to the conjugal home. The wives engaged in a variety of informal labour to make ends meet and were at a stage of their lives in which they could no longer sustain work because of poor health. A number of these women were in the process of divorcing their husbands through khul because they wanted to be eligible for monthly payments from the state's social aid and assistance programme (SAA). According to SAA regulations, in order to receive monthly cash, female beneficiaries have to prove that they have dire economic needs and that they are divorced, widowed, or have been deserted by their husbands for at least four years. In fact, recent studies of government welfare show that programmes such as the SAA are operated on the basis of a philosophy and work practice that gender the roles and needs of its female beneficiaries and expect them to be in abject poverty and without male partner/provider (Bibars 2001; Sabry 2005).

\section{The new Family Courts: implementation challenges}

Effective implementation of the new laws is impaired by a number of shortcomings, which subsequently impact women's access to justice. For instance, the failure to obligate disputants to attend mediation sessions result in making prelitigation mediation an ineffective tool of dispute resolution. In addition, lack of resources and enforcement mechanisms as well as the poor training of court personnel diminish the effectiveness of the alternative mechanisms of dispute resolution which the new court system offers.

Most of all, the legal process in the new court system is gendered through its discourse and practices. In this discourse, women are considered as emotional and hasty, and therefore incapable of making rational decisions about ending their marriages. Some of the interviewed mediation specialists and court experts hold the belief that women resort to khul hastily over petty reasons such as a disagreement over the colour of the upholstery for the furniture in the conjugal home. This scepticism about women's rationality, particularly when it comes to decisions about divorce, is also accompanied by practices that some mediation specialists and judges use when they attempt to reconcile disputants. A common practice is to warn the female disputant of the difficulties and stigma that awaits her if she becomes a divorced woman. In one of the observed court sessions, for example, the senior judge tried to persuade a plaintiff to reconsider her divorce claim by warning her that her young daughter would probably have a difficult life with limited prospects for marriage and respectability if her mother becomes a divorcee through khul. In addition, this legal discourse depicts female sexuality as the object of her husband's control. It is assumed by lawyers and judges that it is men's legal obligation to guard the sexual honour of their wives. Thus, lawyers' briefs and court judgements often contain legal claims that are based on this notion. However, the texts of the substantive laws while affirming men's financial obligation towards their wives do not assign husbands an obligation to protect the sexual honour of their wives.

But women are appropriating the new laws in ways that are advantageous to their individual needs, albeit not necessarily enhancing collective gender equality and justice. For instance, the right to khul is being used by female plaintiffs for a variety of purposes such as to opt out of an abusive marriage without the hassle of proving harm, or to claim welfare benefits which they are denied because of their marital status and the specificity of their lived experiences of economic roles and needs.

Contrary to what the opponents of the khul feared, it is not only rich women who are making use of this new legal right. In fact, our findings show that poor women and those with limited financial means are more likely to resort to khul than other kinds of divorce in which they do not need to relinquish their rights to alimony and the dower. This is because these women lack the financial and familial support needed to go through a long litigation process, which is common in cases of 
divorce on the grounds of harm or abandonment. But it is noteworthy that rather than khul being exercised by women as a right that is equivalent to men's right to unilateral repudiation, it is increasingly becoming a guaranteed pathway to what should have been a judicial divorce on the grounds of harm. The question is: is this outcome empowering to women?

\section{Reform approaches and strategies: lessons learned}

Recent legal reforms in Egyptian family laws were driven by multiple agendas and actors. Legislators, the judiciary, and government officials were keen to get rid of the old court system which was overloaded and inefficient, and put in place accessible, affordable and effective legal services, through developing a concise and comprehensive body of procedural laws, and the establishment of a specialised legal system to handle all family law cases. But the government's efforts in reforming family law also need to be understood within the context of competing and sometimes conflicting agendas. On the one hand, the government is constantly striving to assert its religious legitimacy by partaking in dominant religious discourses that regulate family relations and gender roles. On the other hand, the government sees family law reform as a means of modernising the country, enhancing the development process, and maintaining the support of international organisations that fund the country's various development projects. These conflicting goals have translated into an uneven process of reform in family law (Mashhour 2005; Moors 2003; Singerman 2005).

Abu Odeh (2004) points out that since the codification of family laws, apart from the attempt at revolutionary change by President Sadat in 1979, Egyptian legislators adopted a partial and gradual approach to reform in order to accommodate both the advocates for change and gender equality and the religious establishments. As a result, this approach did not seek to change the hierarchical model of marriage that is sanctioned by Egyptian PSLs in which the husband provides for his wife and in exchange the former is granted more rights. However, Egyptian legislators, Abu Odeh adds, tried to restrict the power that was granted to husbands through a number of reforms such as: extending a husband's maintenance duties towards the wife so as to include payment of the wife's medical expenses as well as food, clothes and shelter; granting the wife the right (albeit restricted one) to judicial divorce; restricting husband's right to unilateral divorce and polygamy through imposing financial deterrence such as payment of maintenance to a divorced wife during the waiting period (idda) and payment of indemnity (mut'a) to a wife divorced against her wishes. Women's rights activists are following a similar trajectory of cautious and piecemeal reform approach. To pass the new laws, concessions were made. Contentious articles were camouflaged in procedural codes. One could argue that gradual changes and procedural reforms are not enough to achieve the goal of a new model of marriage and marital roles that upholds gender equality. Yet recent reforms have given women new legal rights and consequently more choices for women.

In the annual convention held in early November 2008, the National Democratic Party, ruling party of the Egyptian government, announced an initiative to introduce a new family code. This announcement was a culmination of more than a year's efforts by the party's Women's Committee to review the current personal status codes, identify gaps and gender-biased articles, and propose changes. The party presented its proposed draft law to the Ministry of Justice. In addition to the ruling party, the Legislative Committee at the National Council for Women ${ }^{3}$ also drafted a number of amendments to the substantive personal status laws. Government agencies are by no means the only entities which have been working toward reforming personal status laws. Women's rights groups have been very active in advocating for comprehensive legal reforms and have undertaken a number of initiatives to contribute to the process of conceptualising and drafting a new law. There are a number of key proposals that feature in some way or another in the drafts put together by the government and women's rights organisations although the exact details of the final drafts are not known. The proposed changes include: raising the minimum marriage age for women from 16 to 18; redefining existing marital roles in terms that are egalitarian and cooperative rather than hierarchical; abolishing a husband's guardianship over his wife and the latter's legal obligation to obey him; restricting the man's right to unilateral repudiation and 
polygamy; and granting mothers guardianship rights over their children.

Perhaps these proposed changes reflect a shift from a tradition of piecemeal and gradual reform approach to one that is more substantive and seeks to address the root causes of gender inequality and injustice that are inherent in the existing laws. But it is questionable the extent to which the new approach is being fully and effectively adopted. For one thing, reform strategies that are being used by the coalition of reformers remain the same, i.e. top-down and lacking grassroot societal participation. In other words, the processes of formulating and advocating for new laws are still confined to workshops, seminars, conferences, and meetings in which the coalition of reformers mobilise government agencies, members of religious establishments and some representatives of the media. But many sectors of society are either unaware or misinformed of the ongoing reform efforts. These sectors include Egyptian women and men at large (many of our interviewees did not have a good knowledge of the purpose and procedures of newly passed laws such as khul), more diverse public thinkers, the majority of the media, and religious scholars who are not associated with the government or the religious establishment. It follows then that regrettably, none of these sectors are involved in the ongoing reform efforts.

Legal anthropology and feminist legal scholarship have deconstructed the myth of law as a rational positivist entity that exists separate from social structures and processes (Moore 1978; Shehada 2002). The de-centring of law as an objective autonomous body of knowledge or as a bounded and powerful state institution means that we need to be cognisant of the social structures through which legal codes are constructed, interpreted, performed and appropriated. Thus, in 1979, when the late President Sadat decreed a new personal status law that allowed Egyptian married women to automatically file for divorce on the grounds of their husbands' taking another wife, and protected working women from the charge of 'disobedience' and loss of spousal financial support, some of the loudest dissenting voices were those of judges who felt that the new legislation was imposed on them and was in conflict with their (social) understandings of the institution of marriage. The law was revoked by the Higher Supreme Court a few years later on technical grounds. What this example illustrates is the limitations of a top-down reform approach that fails to recognise the socialembeddedness of law and does not link the process of law-making to multilayered engagement with different forces and domains in the society with the aim of creating spaces in which new and just gender roles and relations can be collectively imagined and realised.

I think we are learning the same lesson from the unfolding story of the recent reforms in the family laws. In other words, law-making has to be integrally tied to law acceptance, and this is more likely to be achieved if legal reforms are part and parcel of a larger multilayered and grassroot-based movement for change.

\section{Conclusion: towards just family laws}

Egyptian substantive personal status laws prescribe and affirm a gendered form of marriage that is unjust to women. In this institutional narrative, wives are subordinate, dependent and sexualised. The realities of Egyptian women, however, demonstrate the contradictions and the limitations of the legal model of marriage. In real life, many Egyptian women are not financially dependent on their husbands. The model of spousal financial support in exchange for wifely obedience does not sustain healthy and happy marriages. And women suffer not only because of the contradictions between the legal construction of marriage and their lived realities but also because of their legal discrimination and marginalisation. The recent changes in Egyptian family law have had mixed impact on the legal empowerment of women. Women's rights to divorce have been expanded. A number of procedural reforms have been introduced to make the legal system in family dispute cases accessible, efficient and effective. But these procedural reforms have not been successful in transforming the gendered and hierarchical model of marriage that continues to be reenacted through the existing substantive laws.

It is certain, however, that the new procedural reforms have created a momentum for change and started a journey towards a new and comprehensive substantive family code. Women's rights activists are seeking a new legal model of marriage that is based on equal rights and responsibilities between husband and wives. But such a marriage may entail a number of things 
that will affect women differently. For instance, in this kind of marriage, the wife may no longer enjoy the exclusive right to her own financial assets, which she may be obligated to contribute to the family if there is need. Moreover, it may follow that she will not be able to file for divorce on the grounds of lack of maintenance, if she is financially able. Will this model of marriage be just and good to all Egyptian women? On the one hand, the realities of many Egyptian marriages show that women contribute significantly to the financial support of the family. Yet, unlike their husbands, they do not acquire any legal rights from their financial role. But some women may be ambivalent or even opposed to being legally obligated to contribute to the conjugal household and to give up their claim to the financial support of the husband in exchange for equal marital and parental rights. What about women who are not generating income and do not wish to be employed in the labour market? How will their non-monetary labour be credited in the legal discourse?

\section{Notes}

1 These were religious scholars who are members of the Academy for Islamic Research, which is part of $A l$-Azhar. The Academy is in charge of reviewing draft laws to ensure their compatibility with the principles and injunctions of Shari'a.

2 Up until 1967, wives who were found disobedient by the court could be forcibly returned to the conjugal home by law

\section{References}

Abdel Rahim, A. (1996) 'The Family and Gender Laws in Egypt During the Ottoman Period', in A. Sonbol (ed.), Women, the Family and Divorce Laws in Islamic History, Syracuse NY: Syracuse University Press

Abu Odeh, L. (2004) Modernizing Muslim Family Law: the Case of Egypt, Oxford University Comparative Law Forum 3, http://ouclf.iuscomp.org/articles/abuodeh.shtml (accessed 18 December 2009)

Bibars, I. (2001) Victims and Heroines: Women, Welfare, and the Egyptian State, London: Zed Books

Fawzy, E. (2004) 'Muslim Personal Status Law in Egypt: The Gurrent Situation and Possibilities of Reform through Internal Initiatives', in L. Welchman (ed.), Women's Rights and Islamic Law, New York: Zed Books
Lastly, legal reforms (even the most emancipating ones) are not the end result. These reforms are only meaningful insofar as they actually lead to positive and substantive changes in the lives of those who are targeted by the new laws. This requires adequate and effective mechanisms of implementation and enforcement on the one hand, and a supportive environment on the other. The establishment of the latter takes time but it is more possible if the reform process is participatory and takes place at the grassroot level. In other words, reform strategies need to go beyond lobbying the government. What is lacking in the current reform efforts are building support among different sectors of the society (religious scholars, Islamic NGOs, legislators, families and communities) through dialogue and awareness raising, and partaking in the process of imparting to new generations of children and young people enlightened religious knowledge and sensibilities that are appreciative of justice, equality and acceptance and respect for others.

enforcement officials, if their husbands so wished. The practice was then abolished by a ministerial decree.

3 The National Council for Women was established by the government in 2000. The goals of the council are to promote policies to strengthen women's rights and enhance their development; and monitor the implementation and impact of government policies that pertain to women.

Hallaq, W. (2009) Shari'a: Theory, Practice and Transformation, Cambridge: Cambridge University Press

Mashhour, A. (2005) 'Islamic Law and Gender Equality - Could There be a Common Ground? A Study of Divorce and Polygamy in Shari'a Law and Contemporary Legislation in Tunisia and Egypt', Human Rights Quarterly 27: 562-96

Mir-Hosseini, Z. (2003) 'The Construction of Gender in Islamic Legal Thought and Strategies for Reform', Hawwa 1.1: 1-25 Moore, S.F. (1978) Law as Process: An Anthropological Approach, London: Routledge and Kegan Paul

Moors, A. (2003) 'Public Debates on Family Law Reform: Participants, Positions, and Styles of Argumentation in 1990s', Islamic Law and Society 10.1: 1-11 
Sabry, S. (2005) 'The Social Aid and Assistance Program of the Government of Egypt - A Critical Review', Environment and Urbanization 17: $27-41$

Shehada, N. (2002) 'Justice without Drama: Enacting Family Law in Gaza City Shari'a Court', Doctorate Dissertation, Institute of Social Studies, Gender, Culture, and Development, The Hague, The Netherlands Singerman, D. (2005) 'Rewriting Divorce in

Egypt: Reclaiming Islam, Legal Activism and
Coalition Politics', in R.W. Hefner (ed.), Remaking Muslim Politics: Pluralism, Contestation, and Democratization, Princeton: Princeton University Press

Sonbol, A. (2005) 'History of Marriage Contracts in Egypt', Hawwa 3.2:159-96

Tucker, J. (2008) Women, Family, and Gender in Islamic Law, Cambridge: Cambridge

University Press 